\title{
STUDY ON THE ACIDIFICATION DYNAMICS AND SYNERESIS OF YOGHURT ENRICHED IN GOJI BERRY FRUITS (LICIUM BARBARUM L.)
}

\author{
Ira Taneva ${ }^{1}$, Gordana Dimitrovska ${ }^{2}$ \\ ${ }^{1}$ Faculty of Technics and Technologies of Yambol, \\ Trakia University of Stara Zagora, Bulgaria \\ Graf Ignatiev 38, 8600 Yambol, Bulgaria \\ e-mail: ira_64@abv.bg \\ ${ }^{2}$ St. Kliment Ohridski University of Bitola, Republic of North Macedonia \\ $1^{\text {st }}$ May bb, 7000 Bitola, Republic of North Macedonia \\ e-mail: gordana.dimitrovska@uklo.edu.mk
}

\begin{abstract}
Yoghurt was prepared with addition of 2, 4 and $6 \%$ goji berry fruits with respect to yoghurt mass. From the data on the titratable and active acidity, it can be summarized that the addition of goji berry fruits did not exert effect on the dynamic of acidification and proper course of the lactic acid fermentation in the yoghurts obtained. At the end of the storage periods of the yoghurts containing or not containing goji berry fruits, the active acidity reached up to $\mathrm{pH} 4,1 \div 4,3$ and the titratable acidity up to $140 \div 44^{\circ} \mathrm{T}$. It was found that the addition of dry goji berry fruits improves the syneresis and protects the product from stratification. The lowest syneresis values were observed for sample S3 - 4,1 $\mathrm{cm}^{3}$. The goji berry fruits did not affect the vital activity of the lactic acid bacteria. At the end of the storage period (14 days), the highest number of viable lactic acid bacteria was established in sample S2 - 3,6.10 CFU. $g^{-2}$. This makes the yoghurt obtained beneficial and possessing certain effect on health.
\end{abstract}

Key words: yoghurt , goji berry, dynamics of acidification, syneresis.

\section{INTRODUCTION}

The main process in yoghurt production is the occurring of homofermentative lactic acid fermentation of the lactose during the coagulation of the milk in the thermostatted vessels. Under the influence of the accumulated lactic acid, acid coagulation of casein which ends at titratable acidity of $75 \div 80{ }^{\circ} \mathrm{T}$ and $\mathrm{pH} 4,6 \div 4,7$. At this moment, the yoghurt has thick consistency and does not ooze serum on its surface. Yoghurt structure is formed as a result of disulfide bonding between k-casein and denaturated proteins by casein aggregation whereby the active acidity decreases to the isoelectric point of the casein proteins [5, 9].

Besides the proper carrying out of the coagulation, the separated amount of serum is affected also by the low content of fats, improper heat treatment, low pressure by the process of milk homogenization, disturbance of the coagulum at $\mathrm{pH}>4.6$, etc. The reasons for the exuded amount of serum can be the lack of stabilizer if the lactic acid fermentation occurs with release of great amounts of acid or gas.

The syneresis of dairy products is a process of self-extraction of serum from the coagulum. For dairy products like white cheese, cheese, etc., the synersis is necessary while for other yoghurt beverage products it might damage their consistency. The degree of syneresis is one of the indicators showing the rheological properties of the fermented dairy products because it stipulates the strength of the coagulum and, hence their consumer properties. 


\section{AR'TIE

To decrease the syneresis degree, various natural additives like nuts, extracts from flax or sesame, blueberry or aronia juice, etc. can be used as stabilizers. Together with the reduction of syneresis, they improve its biological wholeness. The enriched dairy products improve the organoleptic, diet and healing properties [7, 12].

The rich chemical composition of the goji berry fruits (Lycium barbarum L.) allows using them as additive in the production of various types of dairy products. The goji berry fruits are rich in: proteins - 55,4 g/ kg; fats - 10,4 g/ kg; carbohydrates - 267,6 g/ kg fibers - 37,4 g/ kg; mineral substances - 13,8 g/ kg (Qian, J. et al 2004).

The high antioxidant activity of goji berry fruits is due to the high content of polyphenols, flavonoids, carotenoids, etc. $[8,11]$. This makes them suitable for addition in both fresh and dried state or as extracts in food products and cosmetics.

Rotar A. et al., 2015, proved that goji berry fruits added to fermented milk increase the viability of the probiotic bacteria during its storage [10].

The aim or the present paper is to study the influence of the added goji berry fruits on the syneresis of the yoghurt obtained and the dynamics of the lactic acid fermentation, as well as on the vital functions of the lactic acid bacteria.

\section{MATERIALS AND METHODS}

\subsection{Materials}

For preparation of yoghurt with and without additive of dry goji berry fruits, milk from cows grown in the region of Yambol was used, with constant composition and properties (fat content $-3,5 \%$; active acidity $\mathrm{pH}-6,6$; dry fatless residue $-8,7 \%$; Lyophilized yeast (Lactobacillus delbreukii ssp bulgaricus, Streptococcus thermophilus) for direct inoculation containing more than $9,5 \times 10^{9} \mathrm{CFU} \cdot \mathrm{g}^{-1}$ lactic acid bacteria, product of "Laktina" PLC, was used as starter culture.

The dry goji berry fruits were purchased on the market. Before use, they were washed, dried and ground to $20 \div 40 \mathrm{~mm}$ flakes and added to the milk in quantities 2,4 and $6 \%$.

\subsection{Methods}

A method for preparation of lactic acid products containing goji berry fruits (Lycium barbarum L.) was developed and it is shown in Figure 1. After quality control, acceptance, filtering and homogenization, the cow's milk was pasteurized at temperature $70 \div 72{ }^{\circ} \mathrm{C}$ for $25 \mathrm{~min}$. The pasteurized milk was cooled to temperature $44 \div 45{ }^{\circ} \mathrm{C}$ and inoculated with lyophilized starter culture (Lactobacillus delbreukii ssp bulgaricus, Streptococcus thermophilus). The amount of inoculant added was $3 \%$ in relation to mass of the milk. The inoculated milk was thermostatted at temperature $42 \div 45{ }^{\circ} \mathrm{C}$ for $3,5 \div 4,0 \mathrm{~h}$. After reaching $\mathrm{pH} 4,6 \div 4,7$, the coagulated milk was homogenized (stirred), the goji berry fruits were added in quantities 2 and $4 \%$ and the mixture was cooled to $18 \div 0{ }^{\circ} \mathrm{C}$ for $1 \frac{1 / 2}{\mathrm{~h}}$. The product obtained was stored at temperature of $0 \div 4{ }^{\circ} \mathrm{C}$. 
Quality control, acceptance, filtering and homogenization of the milk

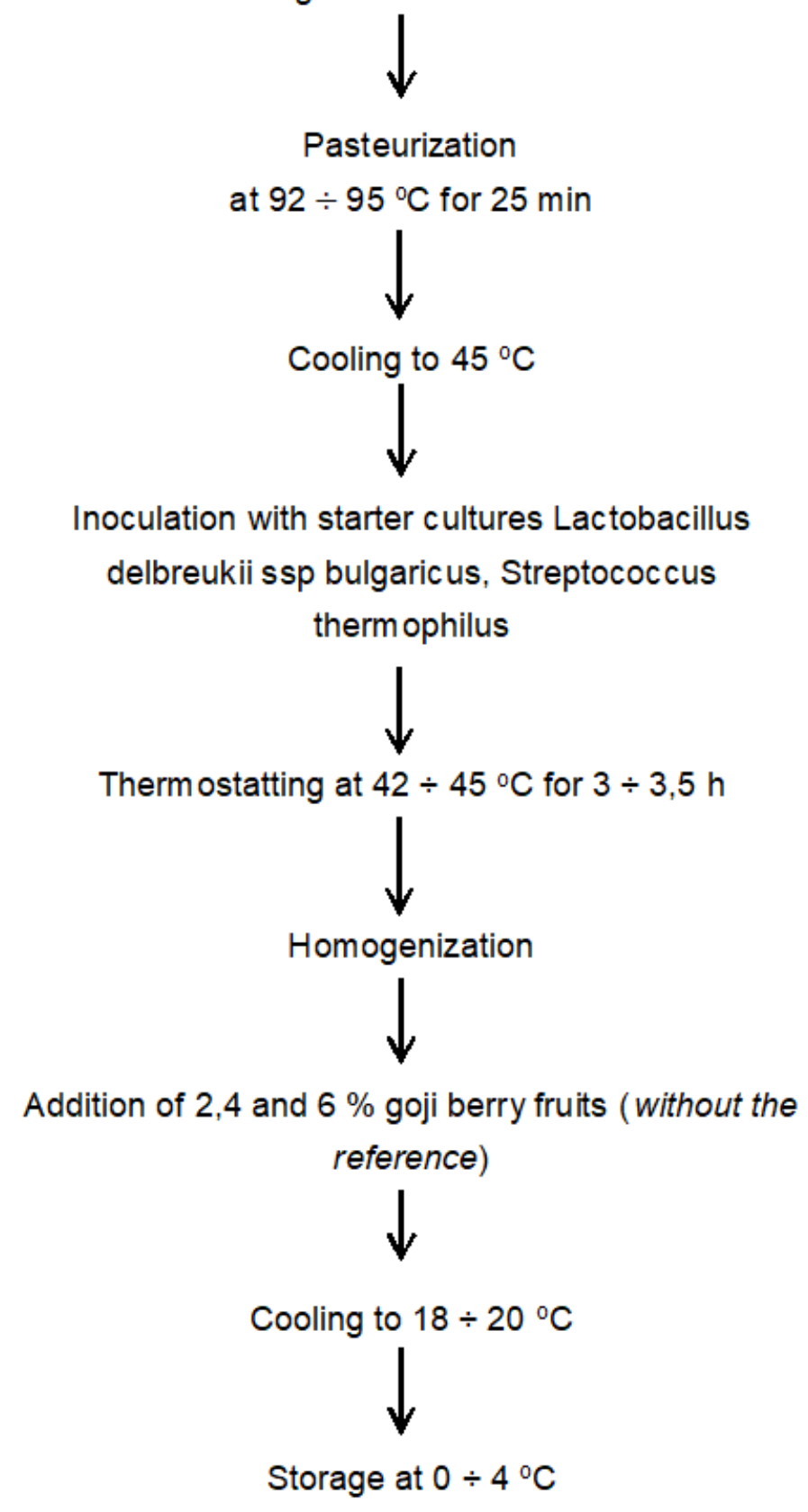

Figure 1. Schematic diagram of the technologic operations for preparation of yoghurt with or without additive of goji berry fruits

Yoghurt analyses - for yoghurts without goji berry fruits $(\mathrm{K})$, yoghurt with $2 \%$ goji berry fruits (S1); yoghurt with $4 \%$ goji berry fruits (S2); yoghurt with $6 \%$ goji berry fruits (S3), the following parameters were determined:

- Dynamics of acidification, by measuring pH by a pH meter (Model MS 2011, Microsyst, Plovdiv, Bulgaria) equipped with electrode ( $\mathrm{pH}$ electrode Sensorex, Garden Grove, CA,

IRTIIE Vol. 7, No. 1, 2019 ISSN 1314-8788 (print), ISSN 1314-8796 (online), doi: 10.15547/artte.2019.01.005 
USA).

- Titratable acidity - BNS 6996:1996 Methods for determining the titratable acidity [2].

- Dimitrov T., G. Mihaylova, T. Iliev, N. Naidenova - Milk and dairy products with methods of analysis, Stara Zagora, 2008 [4].

- Number of lactic acid bacteria - ISO 15214:1998 Microbiology of food and animal feeding stuffs -- Horizontal method for the enumeration of mesophilic lactic acid bacteria -Colony-count technique at 30 degrees $\mathrm{C}$ [6].

\section{RESULTS AND DISCUSSION}

Table 1 shows the results obtained for the dynamics of acidification for yoghurt with and without additive of $2 \%, 4 \%$ and $6 \%$ goji berry fruits.

Table 1. Acidification dynamics in yogurt without and with the addition of berry berries

\begin{tabular}{|c|c|c|c|c|c|c|c|c|}
\hline \multirow{2}{*}{$\begin{array}{c}\text { Time, } \\
\mathbf{h}\end{array}$} & \multicolumn{2}{|c|}{$\begin{array}{l}\text { Yogurt without fruit } \\
\text { Goji Berry } \\
\text { (K) }\end{array}$} & \multicolumn{2}{|c|}{$\begin{array}{l}\text { Yoghurt with } \\
2 \% \text { Goji Berry } \\
\text { (S1) }\end{array}$} & \multicolumn{2}{|c|}{$\begin{array}{l}\text { Yoghurt with } 4 \\
\text { \% Goji Berry } \\
\text { (S2) }\end{array}$} & \multicolumn{2}{|c|}{$\begin{array}{c}\text { Yoghurt with } 6 \% \\
\text { Goji Berry } \\
\text { (S3) }\end{array}$} \\
\hline & $\mathrm{pH}$ & $\begin{array}{c}\text { Titratable } \\
\text { acidity, } \\
{ }^{\circ} \mathrm{T}\end{array}$ & pH & $\begin{array}{l}\text { Titratable } \\
\text { acidity, } \\
{ }^{\circ} \mathrm{T}\end{array}$ & $\mathrm{pH}$ & $\begin{array}{c}\text { Titratable } \\
\text { acidity, } \\
{ }^{\circ} \mathrm{T}\end{array}$ & $\mathrm{pH}$ & $\begin{array}{l}\text { Titratable } \\
\text { acidity, } \\
{ }^{\circ} \mathrm{T}\end{array}$ \\
\hline 0 & 6,60 & 19 & 6,60 & 19 & 6,60 & 19 & 6,60 & 19 \\
\hline 1 & 6,00 & 45 & 6,00 & 45 & 6,00 & 44 & 6,00 & 44 \\
\hline 2 & 5,20 & 65 & 5,50 & 60 & 5,70 & 58 & 5,80 & 58 \\
\hline 3 & 4,70 & 96 & 5,10 & 76 & 5,20 & 66 & 5,30 & 66 \\
\hline 4 & 4,50 & 100 & 4,80 & 96 & 4,90 & 86 & 4,90 & 84 \\
\hline 24 & 4,50 & 110 & 4,40 & 98 & 4,60 & 100 & 4,80 & 110 \\
\hline 48 & 4,40 & 120 & 4,50 & 110 & 4,50 & 106 & 4,60 & 112 \\
\hline 72 & 4,40 & 120 & 4,40 & 116 & 4,40 & 118 & 4,30 & 116 \\
\hline 96 & 4,30 & 124 & 4,30 & 120 & 4,36 & 120 & 4,36 & 120 \\
\hline 120 & 4,30 & 126 & 4,30 & 122 & 4,40 & 122 & 4,32 & 120 \\
\hline 144 & 4,30 & 128 & 4,30 & 120 & 4,20 & 126 & 4,28 & 128 \\
\hline 168 & 4,20 & 128 & 4,20 & 128 & 4,24 & 130 & 4,28 & 132 \\
\hline 192 & 4,20 & 134 & 4,20 & 130 & 4,24 & 138 & 4,24 & 138 \\
\hline 216 & 4,10 & 136 & 4,10 & 138 & 4,10 & 140 & 4,18 & 144 \\
\hline 240 & 4,10 & 144 & 4,16 & 140 & 4,20 & 144 & 4,30 & 144 \\
\hline
\end{tabular}

The coagulation of the reference sample was observed after $3 \mathrm{~h}$ while in the samples containing goji berry fruits the coagulation took $1 \mathrm{~h}$ longer period $-4 \mathrm{~h}$. it can be seen that the acidity of the reference sample and the samples containing goji berry fruits gradually increased. At the third hour of coagulation, the highest acidity was observed for the reference $\left(\mathrm{pH} 4,7\right.$ и $\left.96^{\circ} \mathrm{T}\right)$. The increase of the percentage of goji berry fruits added to the milk slowed the acidification and after 4 hours, the acidity of $\mathrm{S} 1$ was $\mathrm{pH} \mathrm{4,8}$ and $96^{\circ} \mathrm{T}$, for sample $\mathrm{S} 2-\mathrm{pH}$ 4,9 and $86^{\circ} \mathrm{T}$ and for sample S3 - $\mathrm{pH} 4,9$ and $84^{\circ} \mathrm{T}$. After one day of coagulation $(24 \mathrm{~h})$, the titratable acidity of the samples varied from 98 to $110^{\circ} \mathrm{T}$ and the active acidity - in the range $\mathrm{pH} 4,4 \div 4,8$. After $48 \mathrm{~h}$, the acidity of the reference reached $\mathrm{pH} 4,4$ and $120^{\circ} \mathrm{T}$ and these values changed to $\mathrm{pH} 4,2$ and $128^{\circ} \mathrm{T}$ until the $7^{\text {th }}$ day. The samples containing 2,4 and $6 \%$ goji berry fruits showed the same tendency of increasing of the acidity. After the seventh day, within 3 days, the active acidity increased to $\mathrm{pH} 4,1 \div 4,3$ for all the samples studied and the titratable acidity increased to $140 \div 144^{\circ} \mathrm{T}$. 


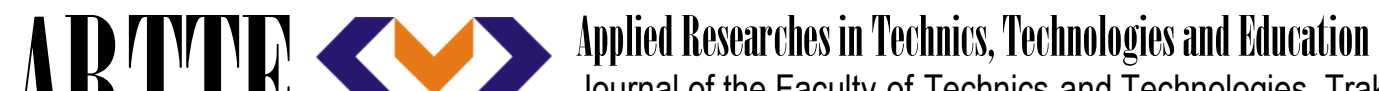 Journal of the Faculty of Technics and Technologies, Trakia University https://sites.google.com/a/trakia-uni.bg/artte/}

Based on the data about the titratable and active acidity, it can be summarized that the addition of 2,4 and $6 \%$ goji berry fruits did not affect the acidification and the proper course of the lactic acid fermentation in the yoghurts obtained.

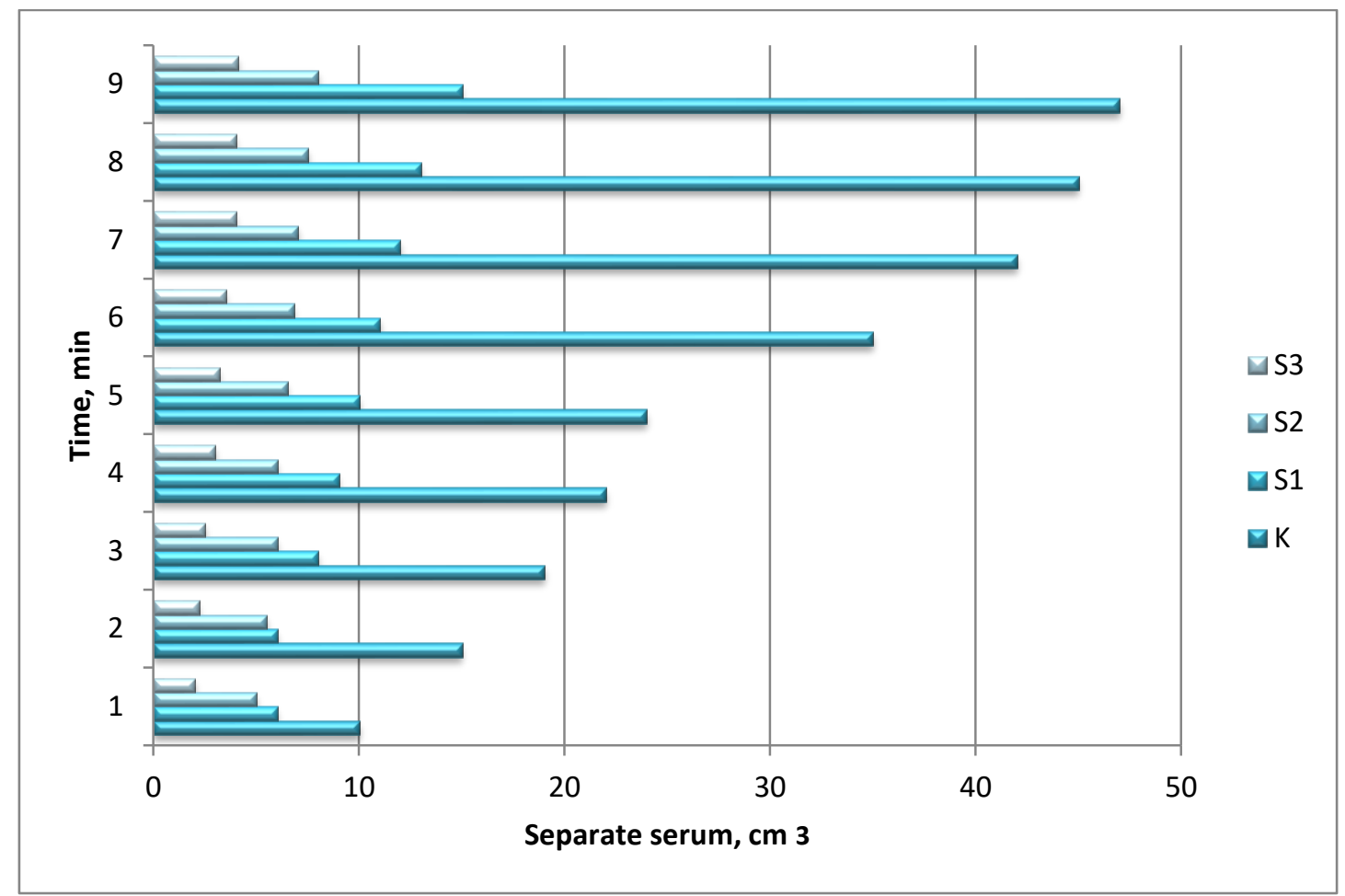

Figure 2. Yogurt syneresis wanting and with Goji Berry

The amount of serum (syneresis) exuded for 5 hours from the yoghurts obtained and the results obtained are presented in Figure 2. Syneresis is an important indicator because it is a criterion for determination of the amount of yoghurt. Higher syneresis level indicates for lower quality yoghurt. The syneresis of yoghurts is substantially affected by the concentration of the fruits added to it. As can be seen, the syneresis for the reference sample was the highest $47 \mathrm{~cm}^{3}$ while for the fruit containing samples S1, S2 and S3 it significantly decreased. The lowest values were observed for sample S3 where for $5 \mathrm{~h}$ the amount exuded was $4,1 \mathrm{~cm}^{3}$. Obviously, the goji berry fruits absorb the water thus reducing the aqueous phase in the yoghurt obtained and improving its structure. Similar results were reported by Amal A et al. (2016) [1] who measured better syneresis values for yoghurts with added cactus pear and papaya.

The data presented in Table 2 showed that the total number of lactic acid bacteria was not affected by the addition of goji berry fruits. During the storage period of all samples, the total number of lactic acid bacteria increased up to the $7^{\text {th }}$ day and the highest number was measured in sample $S 1-2,8.10^{9}$ CFU. $g^{-2}$ while the reference sample contained $1,1.10^{9}$. at the end of the storage period $\left(14^{\text {th }}\right.$ day), the highest number of viable lactic acid bacteria was observed in sample S2 $-3,6.10^{8}$ CFU.g ${ }^{-2}$. 
Table 2. Number of viable lactic acid bacteria in yoghurts with and without additive of goji berry fruits

\begin{tabular}{|c|c|c|c|c|}
\hline \multirow{2}{*}{ Sample } & \multirow{2}{*}{$\begin{array}{c}\text { Storage } \\
\text { duration, } \\
\text { days }\end{array}$} & \multicolumn{3}{|c|}{$\begin{array}{c}\text { Number of viable cells per } 1 \mathrm{~g} \text { product, } \\
\text { CFU / g }\end{array}$} \\
\hline & & L. bulgaricus & Str. thermophilus & Total \\
\hline \multirow{4}{*}{$\mathrm{K}$} & 0 & $1,3.10^{\prime}$ & $4,7.10^{\prime}$ & $6,0.10^{\prime}$ \\
\hline & 3 & $2,4.10^{8}$ & $2,2.10^{9}$ & $2,4.10^{9}$ \\
\hline & 7 & $1,1.10^{8}$ & $1,0.10^{9}$ & $1,1.10^{9}$ \\
\hline & 14 & $2,6.10^{6}$ & $3,1.10^{8}$ & $3,4.10^{8}$ \\
\hline \multirow{4}{*}{ S1 } & 0 & $1,3.10^{\prime}$ & $4,7.10^{\prime}$ & $6,0.10^{\prime}$ \\
\hline & 3 & $1,8.10^{\prime}$ & $2,2.10^{8}$ & $2,3.10^{8}$ \\
\hline & 7 & $1,2.10^{8}$ & $2,7.10^{9}$ & $2,8.10^{9}$ \\
\hline & 14 & $2,3.10^{\prime}$ & $3,1.10^{8}$ & $3,3.10^{8}$ \\
\hline \multirow{4}{*}{ S2 } & 0 & $1,3.10^{\prime}$ & $4,4.10^{\prime}$ & $6,0.10^{\prime}$ \\
\hline & 3 & $2,4.10^{8}$ & $2,8.10^{9}$ & $3,0.10^{9}$ \\
\hline & 7 & $1,2.10^{8}$ & $1,3.10^{9}$ & $1,4.10^{9}$ \\
\hline & 14 & $2,5.10^{\prime}$ & $3,4.10^{8}$ & $3,6.10^{8}$ \\
\hline \multirow{4}{*}{ S3 } & 0 & $1,3.10^{\prime}$ & $4,4.10^{\prime}$ & $6,0.10^{\prime}$ \\
\hline & 3 & $2,1.10^{8}$ & $2,6.10^{9}$ & $2,8.10^{9}$ \\
\hline & 7 & $1,1.10^{8}$ & $1,4.10^{9}$ & $1,5.10^{9}$ \\
\hline & 14 & $2,3.10^{\prime}$ & $3,1.10^{8}$ & $3,3.10^{8}$ \\
\hline
\end{tabular}

This makes the yoghurt obtained valuable and exerting beneficial effect on health. Similar results obtained Stijeptic et al. (2012) who observed slight decrease of the lactic acid bacteria but remaining in quantities enough to be within the requirements of Codex alimentarius (CODEX STAN 243 - 2003) [3]. According to Codex alimentarius, the lactic acid bacteria on fermented dairy products should not be less than $10^{7}$ viable cells.

\section{CONCLUSION}

A method for production of lactic acid dairy products with addition of goji berry fruits (Lycium barbarum L.) was developed. It was found that the addition of dry goji berru fruits in quantities 2, 4 and $6 \%$ in relation to milk mass does not have effect of the dynamics of lactic acid formation, improves the syneresis and protects the product from layering.

The total number of viable bacteria contained in the yoghurts obtained was determined and their number by the end of the storage period complies with the requirements of Codex alimentarius (CODEX STAN 243-2003).

\section{REFERENCES}

[1] Amal A., E.Mahmoud, N. Zidan. (2016). Fruit Flavored Yoghurt: Chemical, Functional and Rheological Properties, International Journal of Environmental \& Agriculture Research (IJOEAR), ISSN:2454-1850, Vol. 2, No. 5, pp. 57-66.

[2] BNS 6996:1996 Methods for determining the titratable acidity. (in Bulgarian).

[3] CODEX STAN 243-2003. Codex Standards for Fermented Milks.

[4] Dimitrov T., G. Mihaylova, T. Iliev, N. Naydenova. (2008). Milk and Dairy Products with Methods of Research, Stara Zagora, 2008. (in Bulgarian).

[5] Donato L. and Guyomarch F. (2009). Formation and properties of the whey protein/jcasein complexes in heated skim milk - A review, Dairy Science and Technoogy 89, pp. 3-29. 


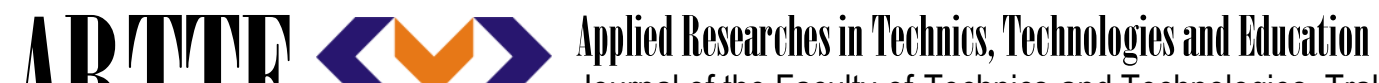 Journal of the Faculty of Technics and Technologies, Trakia University https://sites.google.com/a/trakia-uni.bg/artte/}

[6] ISO 15214:1998. Microbiology of food and animal feeding stuffs - Horizontal method for the enumeration of mesophilic lactic acid bacteria - Colony-count technique at 30 degrees $\mathrm{C}$.

[7] Murgov I. and Z. Denkova. (2007). The place of probiotics and probiotic foods in the protection of public health, National meeting c International Participation „Immunity Support for Health from Nature and Science in Bulgaria“, 19-20 October, Hissarya.

[8] Peng, Y., Ma, C., Li, Y., Leung, K. S., Jiang, Z. H., Zhao, Z. (2005). Quantification of zeaxanthin dipalmitate and total carotenoids in Lycium fruits (fructus Lycii). Plant Foods for Human Nutrition, Vol. 60, pp. 161-164.

[9] Qian, J., Liu, D. and Huang, A. G. (2004). The efficiency of flavonoids in polar extracts of Lycium chinense Mill fruits as free radical scavenger. Food Chem., Vol.87, pp. 283 288.

[10] Rotar A., D. Vodnar, F. Bunghez, G. Catunescu, C. Pop, M. Jimboren, C. Semeniuc. (2015). Effect of Goji Berries and Honey on Lactic Acid Bacteria Viability and Shelf Life Stability of Yoghurt, Not Bot Horti Agrobo, Vol. 43, No. 1, pp. 196-203.

[11] Stijeptic, M., D. Durdevic, J. Jovanaglusac. (2012). Production of low fat yoghurt enriched with different functional ingredients. Quality of Life (Banja Luka), Vol. 3, No. 12, pp. 5-12.

[12] Zlatev, Z., M. Petev, A. Dimitrova, V. Simeonova, S. Dinev, J. Dineva. (2015). Analysis of methods and tools for evaluation the quality of yogurt. Journal of Innovation and entrepreneurship, year III, Vol. 1-2, ISSN 1314-9180, pp. 41-57. 